\title{
A STUDY OF TRANS-CULTURAL IDENTITY IN THE WORKS OF V. S. NAIPAUL
}

\section{DEEPIKA SHEKHAWAT}

Research Scholar, P. G. Department of English, University of Rajasthan, Jaipur, India

\begin{abstract}
Identity of Naipaul has been imposed as a half-finished and amalgam of cultures. This substantially and considerably marks an impact on Naipaul's mental state of being when there arises a question of his identity or his place of belongingness, in this modern conscious world of intellectuals. This agony of diaspora and alienation haunts Naipaul to his inner inconsistencies and existential incompatibilities. Thus the present research oeuvre with the help of the intersection between 'diasporic' and 'postcolonial theories, deals with analyzing Naipaul as a product of the World of literature, whose farfetched literary journey has been an expedition of acknowledging his belongingness and location along with a stigma of trans-cultural identity. This noble offers, a more differentiated and definite view, beyond the assumptions, that have too frequently been taken for granted, and hereby, proffer to substantiate $V$. S Naipaul as an 'epitome' of colonial identity.

KEYWORDS: Post-Colonial, Identity, Third- Worldrers, Alienation, Diaspora \& Trans-Cultural
\end{abstract}

Received: Sep 20, 2017; Accepted: Oct 09, 2017; Published: Nov 04, 2017; Paper Id.: IJELDEC20172

\section{INTRODUCTION}

Vidiyadhar Surajprasad (VS) Naipaul, a 'Postcolonial Mandarin', like the sun piercing the prolonged darkness has emerged on the Britain's soil of colonial writing, as 'aprophet' of our 'world-historical moment', and has created a luminous account of the most compelling literary works, of the last fifty years. ${ }^{1} \mathrm{He}$ is Britain's the only living Nobel laureate(2001), in literature. But, in the case of V. S Naipaul, especially, when issues of identity and home are viewed with a wider sense, neo-colonial view is not a controversial issue to him, but is paramount to changing people's perceptions.

To begin with the term "Identity", it is generally co-related with the nationality, the language, the rights of true citizen of a country, culture and so on. In the current world scenario this term has taken form of one of the most urgent, as well as hotly disputed topics, in literary and cultural studies. "Identity" itself is no singular a question, but constitutes a wide range of questions that are at their best loosely interconnected. However, it is no less than an expedition to every individual that seeks himself to that defines by virtue of his being worth. And perhaps this is a psychological confrontation that occurs to every individual with a history of diaspora, now and again. To be more particular, it has been a central focus of debate for psychoanalytic, poststructuralist, and cultural materialist criticism. Simultaneously, it has also been subjected to a searching critique of the post-colonial world.

Critics agree on to comment that Naipaul is almost fit and fine to claim this identity acquired into a new 'cultural hybridism' at once, on behalf of certain facts: First, his childhood Trinidad being, a former British colony; second, he migrated from Trinidad to England for his education and started and continued his career as a writer; and third, he was descendent of a migrant family, as his ancestors came to Trinidad from India as 
indentured labourers, all of these countries being the former colonies of the British Empire. Thus, he is a writer from 'a country with a history of colonialism'. Naipaul, in one of his texts in a sequence, comments, 'People come and go all the time; the world has always been in movement.' His philosophical text, A Way in the World (1994) inculcates a clustered but interwoven ideology. Now, he establishes himself into a community of travel writers whose expeditions are temporally wide-ranging from India to Trinidad to Oxford (London) as well as encompasses the three worlds of socio-cultural space. Naipaul declares in his 2001 Nobel lecture that his 'aim has always been to fill out [his] world picture', and this travel writing is the greatest aid which extended technically, allowing him to take in a wider and more complex 'world view'. These comments seem to support readings of his work as 'trans-spatial' and 'trans-cultural'.

Like Naipaul, are certain contemporary writers who stand on parallel like, Salman Rushdie, Ben Okri and also of the young writers like Aleksander Hemon etc., who aspire to the similar canon of the British descent. Their habitat has been formed strictly by their culture where they have lived and developed into. They too bear an exclusive identity of home with certain amount of western culture. Naipaul in his above mentioned three worlds has made various searches for his roots, via transitional-socio-cultural changes. On the same hand, the spirit of exile and alienation enriches his diasporic sense of literary art that makes a permanent place among his readers. He tries to salvage his own family history and their deep history, of which he has been the part, and successfully derives a new world, attaining the identity fulfillment.

If truth be spoken, Naipaul has had more or less, a nomadic experience, that too always haunted by the conditions of rootlessness and homelessness. The trajectory that this paper has followed is to probe into Naipaul's reconstructed history through his fractured and fragmented memories of colonial worlds -India, Trinidad and London.

\section{HIS ANCESTRAL LAND: THE INDIAN CONTINENT}

To begin with Naipaul's land of ancestors, the Indian continent, to which Naipaul has reflected in his long fifty years of writing and a close watcher of Indian social milieu. As a consequence, he penned the major books on India, like, An Area of Darkness (1964), India: A Wounded Civilization (1977) India: A Million Mutinies Now (1990) and Half A Life (2001) that are well taken as his homage and also a protest towards it. His deep antipathy becomes apparent when he ones said:

"India is for me a difficult country. It isn't my home and cannot be my home: and yet I cannot reject it or be indifferent to it: I cannot travel only for the sights. I am at once too close and too far."2

Naipaul's travelogues book, An Area of Darkness (1964), seriously examines his authenticity of observations. Naipaul in his thirties he made the first visit, to his ancestral land and depicted the dirt and squalor of his ancestral India. Naipaul writes:

"They (Indians) defecate, mostly beside the railway tracks. But they also defecate on the beaches, hills, riverbanks, streets; they never look for cover. ... But this is a religious act of self-denial, for it is said that the peasant, Muslim or Hindu, suffer from claustrophobia if he has to use an enclosed latrine." 3

He very ironically adds,

India is poor: the fact has only recently begun to be observed in India, with the great growth in population, the choking of the cities, the political assertiveness of industrial workers. To many Indians, however, poverty, just discovered, also seems to have just created.(113) 
Naipaul dares to put forth the very truth about Indian life and culture can be understood only in terms of his expatriate sensibility and his triple identity. He adds that his ancestors accepted the multiracial society although they remained with their individual culture and identity. Indian facelessness attitude has always threatened to Naipaul. He hated the crowd looked like him disabling him with his distinctiveness from them. Thus it can be concluded that he fails to deny the colonial impact, on both himself and his ancestors originating from the eastern world.

\section{TRINIDAD: NAIPAUL'S IMPULSIVE WORLD}

The second phase of his identity attempts to shadow his second world-Trinidad and Tobago, where Naipaul was born in Chaguanas, near Port of Spain. Being poverty-stricken, his ancestors were transplanted from India to Trinidad. But there was no other way than to face this trauma experience, and move to an unknown island to get rid of misfortune and curse of poverty spread in their native land- India. In fact it was a colonial enterprise for the benefit of the colonizers, as took advantage of their poverty and distress. This 'darkness' always instigated Naipaul to undergo from a sense of nonbelongingness to alienation with a loss of identity assuming as an 'in-between worldrers'. On the land of Trinidad Naipaul fulfilled the desire of his father, Seepersad Naipaul, to become a writer in order to escape this existential tyranny, it was nearly impossible task for Naipaul to get out of this land of impossibilities and fulfill and realize his father dreams.

However, with his hard-won scholarship he went to Oxford as he describes it in one of his essays:

I decided to go to Oxford and do the three-year English course. I didn't do this for the sake of Oxford and the English course; I knew little enough about either. I did it mainly to get away to the bigger world and give myself time to live up to fantasy and become a writer. ${ }^{4}$

The same view is noted in his essay "Prologue to an Autobiography" of the same collection: "I decided to use mine [scholarship] to do English at Oxford. I didn't want a degree; I wanted only to get away...” (77)

Paradoxically but true, Trinidad has remained the source and inspiration of the most popular and early works such as, The Mystic Masseur, Miguel Street and A House for Mr. Biswas.

It would be worth quoting, in one of the letters of Naipaul to his mother written from Oxford on $3^{\text {rd }}$ May, 1954 :

The fact is this: I don't see myself fitting into the Trinidad way of life. I think I shall die if I had to spend the rest of my life in Trinidad. The place is too small, the values are all wrong, and the people are petty. Besides, there is really very little for me to do there. Ideally, I would like first of all to arrange for some sort of job in India or elsewhere, and then come home for a vacation, which I do desperately need. [...] Do not imagine that I am enjoying staying in this country. This country is hot with racial prejudices, and I certainly don't wish to stay here. My antipathy to a prolonged stay in this country is as great as my fear of Trinidad. ${ }^{5}$

It is worth noting that Naipaul kept on visiting Trinidad, on a regularly even after the official tour of 1960 when Naipaul summed up the satirical work The Middle Passage. He came back to Trinidadian island in the years, 1965, 1972, 1973, 1977, 1990 and 1992, respectively.

Also, the social evil of beggary can be seen everywhere in the West Indies. Once when Mr. Biswas through his phase of struggle was roaming about in the streets of Port of Spain, he happened to come to the Red House -the court, where he saw "the professional beggars lounged about the bandstand and on benches, so confident of their appearance that they disdained to beg." 6 
Another thing is that the Caribbean society is economically, very poor. The population of the poor is very high and to come across a withered and decrepit Negro is a common sight. The protagonist of The Mimic Men (1967), gives the fine details of poverty in Windies. A day when the child Ralph Singh, with his father and sisters, went for an outing in car, they "went through purely Mulatto Villages where the people were a baked copper colour, much disfigured by disease. They were a small community, exceedingly poor ...now inbred to degeneracy.”(130)

Racial conflicts and tensions in the societies, are pretty ordinary things that duly subsist where the Negroes and the Whites live together, but the Caribbean society in fact teeters on the brink of racial war. The inborn ill feeling of blacks and whites for each other is also very well-known. The Negroes desire to assert themselves, creates a dilemma in Naipaul in a form of psychological collision with white, coloured, Chinese, Syrians and Jews in Jamaica; white and coloured in Martinique; Indians in Trinidad. Nearly, every society in South America is prejudiced to persons of other colours. The Negroes and Indian both sides believe that they can win unaware of the fact that this internal rivalry can destroy both. Thus, in both West Indies and South America violence and brutality became an accepted form in society, almost every society.

Naipaul without hesitation condemns Trinidad that Modernity has no desired impact on any aspect of these societies. The West Indians' attitude is full of cynicism. It has no value for anything. It is a place where "brilliant men, scholarship winners, who had died young, gone mad, or taken to drink... for talent, a futility, the Trinidadian substituted intrigue."7 It is still a place where "dignity was allowed to no one. Every person of eminence was held to be crooked and contemptible." Naipaul's recurring words of abuse for these unruly societies (but England), saying these societies "denied itself heroes. Generosity -the admiration of equal for equal -was there for unknown; it was a quality I knew only from books and found only in England." (35)

He realizes that no skills are required by these societies which produce nothing, and had no ideology or outlook for their own civilization.

\section{THE GREAT BRITAIN ISLAND}

Touching his third world The Great Britain, as his discovery of newness in his life, but still discontented, Naipaul says;

"I came to London. It had become the center of my world and I had worked hard to come to it. And I was lost. London was not the centre of my world. I had been misled; but there was nowhere else to go." 8

Great Britain, where he received his education and had a rise of a noble career of a writer and so on, continued to flourish, finally assimilated him into the colonialism with a complete body and soul. Still, a major work of Naipaul, has stimulated disagreement to his ideology of the three worlds. But it is equally accepted fact that the colonial Great Britain has earned distinctions upon him with so many prizes and accolades, and dignified him as a universal colonial writer, surely, assisted him in sustaining with a high profile post-colonial writer, in the post-colonial societies for which he speaks great of the moral principles of the Western Civilization. It had a kind of security. Naipaul reciprocates this ambivalent reaction by saying:

To be a colonial was to know a kind of security; it was to inhabit a fixed world. And I suppose that in my fantasy I had seen myself coming to England as to some purely literary region, where, untrammeled by the accidents of history or background, I could make a romantic career for myself as a writer. ${ }^{9}$ 
Naipaul, as a keen observer of the English society, unveiled all the truths in his oeuvres. Naipaul doesn't even forgive British history, civilization and its prevailing social defects and keeps a dispassionate distance. He writes (with illustration) that every British Intellectual is persisted with perversion.

Of course, only in the western land, he possibly constructed a new identity, that imbibed with colonial culture. But he feels, the English world is a prejudiced and biased one. Naipaul reiterates to his audiences himself accepting

"It is very strange relationship with England. I have no English audience because English people don't read my books ... It is very strange. I've spent 42 years here as a writer and have no English readership."10

But once having been to London, he ever wished to adopt it for his further life. He now, did not like the idea of returning back home, just like the characters of his works. "I passionately wanted, though hardly arrived in London, to be free of London, I didn't want to go back home, though; I knew there was nothing there. ...I just wanted that day to feel that England was temporary for me too."

Owing much to a universal identity, Naipaul still struggled hard to cope with the stigma of a floating identity which he had never expected, in the Western society. Inspite of all Considering Naipaul, as a universal writer as well as a human, it would not be an admiration to unveil what he has often reiterated at many moments, either in his books or lectures. Quoting the unforgettable Nobel is worth acknowledging:

"When I became a writer, those areas of darkness around me as a child became my subjects. The land; the aborigines; the New World; the colony; the history; India; the Muslim world, to which I also felt myself related; Africa; and then England, where I was doing my writing. That was what I meant when I said that my books stand one on the other, and that I am sum of my books. That was what I meant when I said that my background, the source and prompting of my work, was at once exceedingly simple and exceedingly complicated."11

In a nut shell the three worlds of V. S. Naipaul are consistently apparent in his euphuistic oeuvres that embody the identity quest that reveals the alienation and confronts him in every facet of existence which is a further demonstration of their chequered history. Naipaul shares this burden and wounds of the homelessness and incognito identity.

\section{CONCLUSIONS}

Thus, this paper pursuit successfully makes a humble effort to move beyond the assumptions, and offer a more differentiated and definite view, of what has too frequently been taken for granted, and hereby, proffer to substantiate V. S Naipaul as an "epitome" and "a front man" of the dominating culture: the "colonial culture" and explore the original themes prevalent in his works and also examines his advancement from a regional writer to one with more worldwide allure, whose novels are viewed as representing a turning point in his exaltation and effectiveness as a colonial writer. This ideology, in a way, encompasses all his three worlds, as well.

To conclude, a perceptive study of Naipaul's 'literary fount' reveals, that he subsists, entirely under the interpretation and dominion, of trans cultural condition of identity on the most, the fusion of identity and culture begins from his from the origin of his ancestral place, India to that of his very childhood Trinidad touching the British-London and also the most of the colonial spheres that founds the center. 


\section{REFERENCES}

1. SunilPathak, et al. "V. S. Naipaul in the Line and Light of Colonial Culture." International Journal of Recent Research and Review. Vol II, June 2012.

2. V. S. Naipaul, India: A Wounded Civilization. London: Penguin Books, 1979, p. ix.

3. V. S. Naipaul, An Area of Darkness. London: Picador, 1995. op. cit., p. 70.

4. V. S. Naipaul, Literary Occasions: Essays, London: Picador, 2004. p. 12.

5. V. S. Naipaul, Letters Between A Father and Son. London: Abacus, 1999, pp. 313-314.

6. V. S. Naipaul, The Mystic Masseur. London: Picador, 2001, p. 317.

7. V. S. Naipaul, The Middle Passage, London: Andre Deutch, 1973. p. 35.

8. Cudjoe, Selwyn. V. S. Naipaul: A Materialist Reading. Amherst: The University of Massachusetts Press, 1988, p.21.

9. Literary Occasions, p.170.

10. Singh, Manjit Inder. V. S. Naipaul. Jaipur: Rawat Publications, 2002, p. 23.

11. Literary Occasions, p.190. 